ISSN 1678-3921

Journal homepage: www.embrapa.br/pab

For manuscript submission and journal contents, access: www.scielo.br/pab

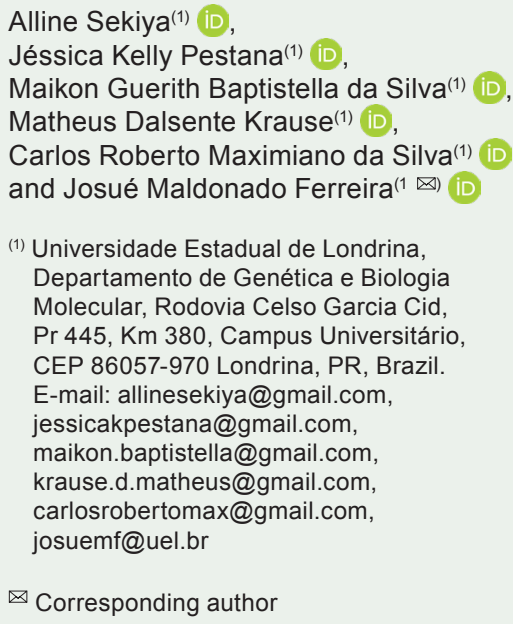

Received

August 02, 2018

Accepted

April 23, 2020

How to cite

SEKIYA, A.; PESTANA, J.K.; SILVA, M.G.B. da; KRAUSE, M.D.; SILVA, C.R.M. da; FERREIRA, J.M. Haploid induction in tropical supersweet corn and ploidy determination at the seedling stage. Pesquisa Agropecuária Brasileira, v.55, e00968, 2020. DOI: https://doi. org/10.1590/S1678-3921.pab2020.v55.00968.

\section{Haploid induction in tropical supersweet corn and ploidy determination at the seedling stage}

\begin{abstract}
The objective of this work was to determine the possibility of haploid induction in tropical supersweet corn (Zea mays L. var. saccharata) using a maternal inducer, as well as to identify alternative methods for haploid selection. A single-cross hybrid of field corn and 11 tropical supersweet corn populations were crossed with the haploid inducer. The haploids were preselected using the R1-navajo marker and were differentiated into haploids or false positives at the V2-V3 stage, based on the color of the first leaf sheath and on the length of stomata guard cells. The obtained results are indicative of the possibility of inducing maternal haploids in populations of tropical supersweet corn. However, a large number of false-positive haploids were incorrectly selected by the R1-navajo marker. The color of the first leaf sheath was efficient for haploid identification in supersweet corn populations, and the method based on stomata morphometry can be used when there is no color distinction on the first leaf sheath.
\end{abstract}

Index terms: Zea mays L. var. saccharata, doubled haploid, haploid induction rate, R1-navajo, stomata.

\section{Indução de haploides em milho tropical superdoce e determinação de ploidia no estágio de plântulas}

Resumo - O objetivo deste trabalho foi verificar a possibilidade de indução de haploidia em milho superdoce tropical (Zea mays L. var. saccharata) por meio de indutor maternal, bem como identificar métodos alternativos para seleção de haploides. Um híbrido simples de milho comum e 11 populações de milho superdoce tropical foram cruzados com o indutor de haploidia. Os haploides foram pré-selecionados pelo marcador R1-navajo e diferenciados em haploides ou falsos positivos, no estágio V2-V3, com base na cor da primeira bainha foliar e no comprimento das células-guarda dos estômatos foliares. Os resultados obtidos são indicativos da possibilidade de induzir haploides maternos em populações de milho superdoce tropical. Contudo, muitos haploides falso-positivos foram selecionados incorretamente pelo marcador R1-navajo. A coloração da primeira bainha foliar foi eficiente na identificação de haploides em populações de milho superdoce, e o método baseado na morfometria dos estômatos pode ser usado quando não há distinção de cor da primeira bainha foliar.

Termos para indexação: Zea mays L. var. saccharata, duplo haploide, taxa de indução de haploide, Rl-navajo, estômatos. 


\section{Introduction}

Corn is one of the main crops used in animal feed and as a food source for humans. Specifically for human consumption, supersweet corn (Zea mays L. var. saccharata), originating from natural recessive mutations, is characterized by a sweet taste, thin pericarp, and delicate texture (Kwiatkowski \& Clemente, 2007). In several countries, the market for canned/tinned and frozen supersweet corn has become an important commodity (Abd El-Hamed et al., 2011), and the development of new commercial hybrids is necessary to meet the requirements of industrial standardization and productivity.

The conventional methods for obtaining inbred lines consist of five to seven self-pollination cycles, representing the most time-consuming stage of the hybrid production process. In contrast, the doubledhaploid technology allows for obtaining completely homozygous inbred lines in two or three generations through the following steps: haploid induction, chromosome doubling, and seed multiplication (Prasanna et al., 2012). The most common approach for haploid induction involves crossing with maternal inducer genotypes used as pollen donors (Prigge et al., 2012b). Wu et al. (2014) identified loci responsive to haploid induction in induced genotypes, highlighting the importance of the genetic constitution of both genotypes involved in the cross to obtain new maternal haploids (Prigge et al., 2011).

Although the majority of inducers are suited to temperate climates (Prigge et al., 2011, 2012a), they show a great potential for development in tropical environments and application in different germplasms. In those genotypes, the anthocyanin gene Rl-navajo $(R I-n j)$ allows for pre-selection of haploid seeds by conferring the endosperm a purple color. However, environmental factors and gene inhibitors may cause variation in the intensity of the purple coloration (Chaikam \& Prasanna, 2012), and mistakes in haploid selection increase the number of plants required at later stages of the process and, consequently, production costs.

Currently, in plant breeding, the main protocols to promote chromosome doubling of haploid individuals involve treatment with a colchicine solution, which is either used to submerge seedlings three to four days after germination (Prasanna et al., 2012) or their roots (Couto et al., 2015) or is directly injected at the beginning of stage V3-V4 (Brenner et al., 2012). Therefore, identifying true haploids in early stages of plant development is crucial to reduce the number of plants to be treated with colchicine, an expensive and highly toxic product.

There are several studies on doubled-haploid production in field corn breeding, involving the steps: haploid induction, chromosome doubling (Kato, 2002; Castillo et al., 2009; Couto et al., 2015), and selection (Prigge et al., 2012b; Beyene et al., 2013; Krchov \& Bernardo, 2015) and use of doubled-haploid lines (Dang et al., 2012; Lübberstedt \& Frei, 2012). In addition, there are indications of haploid induction in temperate genotypes of sweet corn (Zhang et al., 2008; Qiu et al., 2014). However, Tracy (2001) reported that supersweet corn genotypes often carry the C1-I allele, which induces the anthocyanin repressor conditioned by the $\mathrm{C} 1$ protein, preventing haploid selection (Chaikam et al., 2015).

The objective of this work was to determine the possibility of haploid induction in tropical supersweet corn using a maternal inducer, as well as to identify alternative methods for haploid selection.

\section{Materials and Methods}

During the 2013/2014 crop season, 11 supersweet corn populations (PD1003 and PD1010 containing gene bt2; and PD2001, PD2002, PD2003, SD3001, SD3002, SD3004 SD3005, SD3006, and SD3007 containing gene sh2) were pollinated by the inducer population PI4001 at the experimental field of Universidade Estadual de Londrina (UEL), in the state of Paraná, Brazil. In the study, the single-cross hybrid of field corn, 30F53, was used as the control. The supersweet populations were developed by the corn breeding program of UEL, based on backcrosses between supersweet hybrids, used as donors, and field corn populations, as recurring parents, which were also developed by this breeding program.

The seeds obtained from each cross were classified according to the $R 1-n j$ marker, as: class 1 , diploid seeds with purple endosperm and embryo; class 2, putative haploid seeds with purple endosperm and non-purple embryo; and class 3, seeds without marking and with non-purple endosperm and embryo (Dang et al., 2012). The haploid induction rates obtained by $R 1-n j\left(\mathrm{HIR}_{R I-n j}\right)$ 
were estimated using the number of class 2 seeds per total number of seeds.

In a greenhouse, fournon-inducer parental seeds, four class 1 seeds, and 100 class 2 seeds from each population and their crosses were sown in $4.5 \times 4.5 \times 6.0-\mathrm{cm}$ pots, containing a mixture of soil, organic fertilizer, and sand at a ratio of 3:3:2. At the V2-V3 stage, the seedlings were transplanted into $20-\mathrm{L}$ pots with the same substrate. Class 2 seedlings were separated by the first-leaf sheath color, which is mostly green in the parental supersweet corn populations and purple in the inducer and in the 30F53 hybrid (control).

In order to confirm the ploidy status of the putative haploids for each cross during transplanting, samples of root tips were collected from all class 2 seedlings that presented a green first leaf sheath or albino phenotype, and also from five class 2 seedlings that presented a purple first leaf sheath. The samples were pre-treated with $0.05 \%$ colchicine for 2 hours, fixed in ethanol/acetic acid (3:1, v:v) solution for 24 hours, and kept at $-20^{\circ} \mathrm{C}$ until use. This material was then hydrolyzed in $1 \mathrm{~N} \mathrm{HCl}$ at $60^{\circ} \mathrm{C}$ for $12 \mathrm{~min}$, washed with distilled water, and crushed in a drop of $60 \%$ acetic acid. Samples on slides were stained with $2 \%$ Giemsa. Metaphase images for chromosome counts were obtained at 100x magnification using the Motic Images Advanced software, version 3.2 (Motic Asia, Hong Kong, China), with the Leica DM 2000 microscope (Leica Microsystems GmbH, Wetzlar, Germany) connected to a Moticam Pro 282B camera (Motic Asia, Hong Kong, China). Diploid seedlings were characterized by the presence of metaphases with more than ten chromosomes, one of which should present the complete diploid corn genome $(2 x=20)$. Haploid seedlings were defined by the absence of metaphases with more than ten chromosomes, of which at least five should have the complete chromosome number of a haploid cell $(\mathrm{x}=10)$.

Using the methodology of Choe et al. (2012), prints from the bottom surface of the third leaf of the plants were placed on microscope slides. The images were obtained under the FLoid Cell Imaging Station microscope (Thermo Fisher Scientific, Waltham, MA, USA) at a magnification of 460x. For each plant, eight representative guard-cell lengths $(\mu \mathrm{m})$ were measured using the MicroMeasure software, version 3.0 (Colorado State University, Fort Collins, CO, USA), with a standardized scale.
The factorial analysis of variance (Anova) was applied to 12 populations and to the following four categories: PDP, parental diploid plants; DPF1, F1 diploid plants obtained from seeds with purple endosperm and embryo; HPD, false positive haploids represented by plants with $2 \mathrm{x}=20$ chromosomes obtained from seeds with purple endosperm and nonpurple embryo; and $\mathrm{HPH}$, true haploids represented by plants with $\mathrm{x}=10$ chromosomes obtained from seeds with purple endosperm and non-purple embryo.

The plants were considered as replicates in a completely randomized experimental design. For the PDP and DPF1 categories, four plants of each population were evaluated; and, for the HPD category, four plants of the 30F53 and SD3007 hybrid populations, and five plants of the other populations were assessed. However, the number of replicates for the HPH category was defined either by the number of true haploid plants available or by the first-leaf sheath color and chromosome counting of 2 to 16 plants per population. The absence of the HPH category for the 30F53 hybrid (control) produced an incomplete factorial data, and 32 degrees of freedom were obtained for the population $\mathrm{x}$ category interaction.

For each plant considered as a replicate, the average value of eight measurements of stomata guard cells was used for analyses. The Anova and comparison of means using Tukey's test were performed with the GLM procedure for unbalanced and incomplete factorial data of the SAS software, version 9.0 (SAS Institute Inc., Cary, NC, USA).

Using the average of the eight stomata guard-cell measurements for each plant, confidence intervals were estimated both for the average of each category within each cross and for the overall average, at a confidence level of $95 \%$. In the crosses with significant differences between diploid and haploid plants, the ploidy level of class 2 plants not assessed by chromosome counting was considered to be haploid when the average stomata measurements were lower than the upper limit of the HPH category, as defined by the confidence intervals. Since the 30F53 hybrid (control) has no HPH category, haploid plants were selected using the same limit of the overall average of all populations.

The true haploid rate was obtained as the ratio between the number of true haploids (pre-selected as class 2 seeds by $R 1-n j$ and also confirmed as haploids by first-leaf sheath color and chromosome counting) 
and 100 class 2 plants grown in the greenhouse for each population. For 30F53 (control), the total number of true haploids was determined by the morphometric analysis of stomata guard cells.

\section{Results and Discussion}

The PI4001 inducer expressed the $R I-n j$ gene in all populations and in the control; therefore, seeds could be classified as diploid (class 1), putative haploid (class 2), and without marking (class 3) (Figure 1). For populations SD3002, SD3004, SD3005, and SD3006, more than $90 \%$ of the grains were well marked, showing low percentages of class 3 seeds (Table 1), which were between 35 and $72 \%$ for the other supersweet corn populations. Only a small portion of the offspring showed variation in color intensity, as in the experiments of Eder \& Chalyk (2002) carried out with field corn. In the experimental condition of the present study, the control had $26.1 \%$ grains without marking, and the supersweet corn populations showed, on average, $32.7 \%$ class 3 seeds, with a wide range of
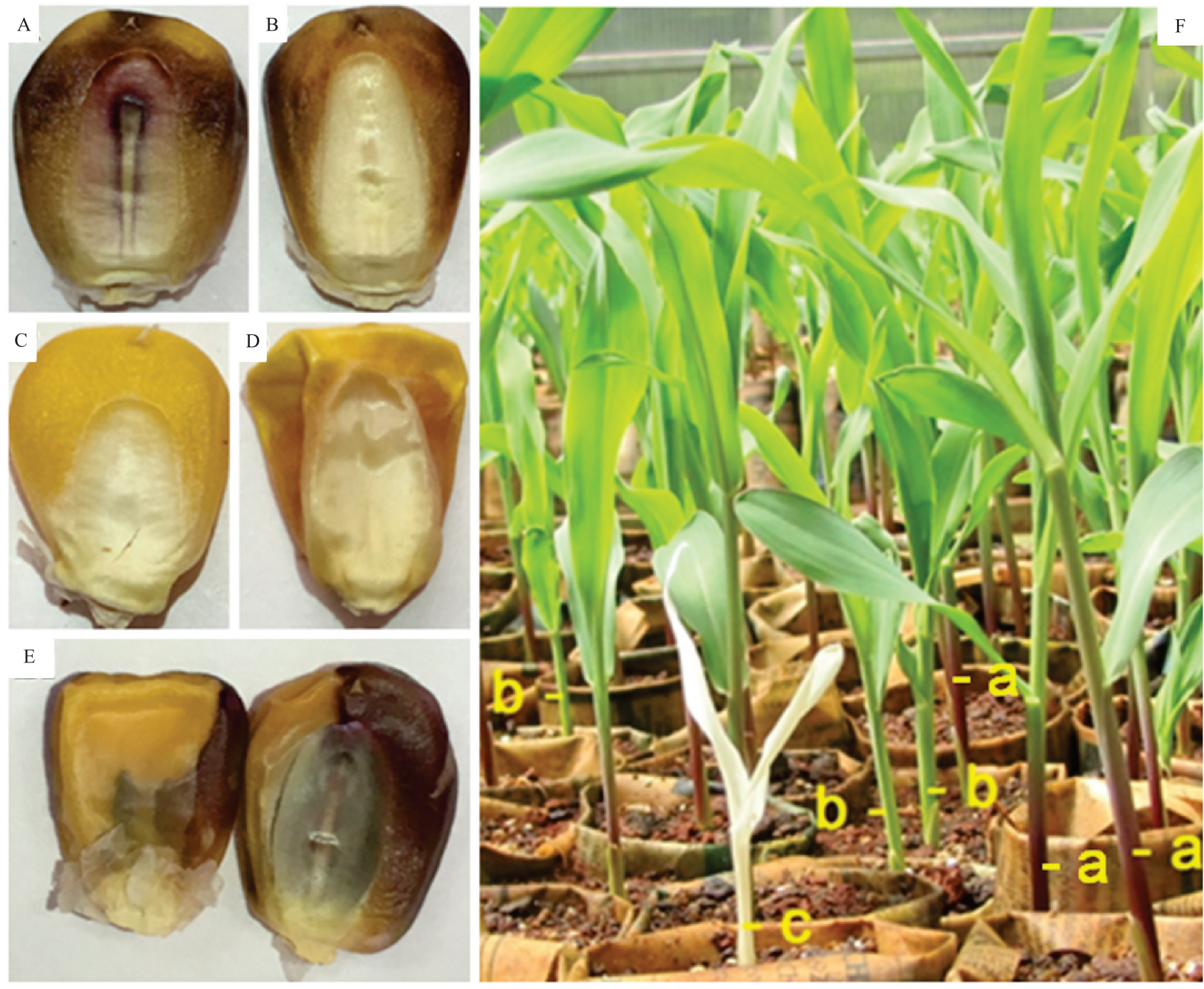

Photo by Josué Maldonado Ferreira

Figure 1. Seed classification and mosaic seeds obtained by the process of haploid induction in supersweet corn (Zea mays L. var. saccharata) populations. A, class 1, diploid seed; B, class 2, putative haploid seed; C, class 3, seed without marking; $\mathrm{D}$, parental supersweet corn seed; E, front and rear vision of mosaic seeds; and F, putative haploid seedlings at the V2-V3 stage, showing seedlings with purple first leaf sheath (a), seedlings with green first leaf sheath (b), and albino seedling (c). 
values. These results could reflect the possibility of applying the $R l-n j$ marker for the selection of putative haploids, as already done in field corn. Tropical supersweet corn populations had similar proportions of grains well marked by the $R 1-n j$ gene, when compared with the control, even possibly carrying anthocyanininhibitor alleles, as evidenced by Tracy (2001) for sweet and supersweet corn genotypes. Furthermore, the presence of four populations with class 3 rates much lower than those of the control enhances the opportunity for future breeding crosses, aiming higher rates of well-marked grains.

In the comparison of the $\mathrm{HIR}_{R I-n j}$, or percentage of class 2 seeds, the 30F53 hybrid (control) showed $5.68 \%$ more putative haploids than the average of the supersweet corn populations (Table 1). The supersweet corn genotypes PD1003, SD3002, and SD3005

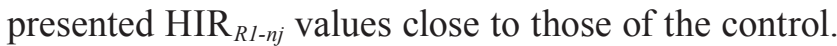
The variation in the $\operatorname{HIR}_{R l-n j}$ observed among the supersweet corn populations showed that the induction rate ranged according to the population used as the female in the induction cross. Some studies have also reported variations in the $\mathrm{HIR}_{R I-n j}$ for field corn used as a pollen receptor, ranging from 6.3 to $10.0 \%$ (Prigge et al., 2011), 3.7 to $19.7 \%$ (Couto et al., 2015), and 0.0 to $32.1 \%$ (Battistelli et al., 2013). In the work of Battistelli et al. (2013), the HIR $R 1-n j$ for the cross between the 30F53 hybrid and the maternal inducer Krasnodar embryo marker synthetic (KEMS) was, on average, $7.35 \%$. In supersweet corn, Zhang et al. (2008) identified 12.65\% putative haploids using $R 1-n j$. These data suggest that field-corn haploid inducers produce supersweet corn haploids in proportions similar to those of field corn.

Table 1. Percentage of seeds classified by the Rl-navajo (Rl-nj) marker in crossings for haploidy induction between 11 supersweet corn (Zea mays L. var. saccharata) populations and a control, rates of true haploids and false positives, correlation between seeds without $R 1-n j$ marking and identified haploids, and factorial analysis of variance for the 12 plant populations and four categories evaluated for stomata guard-cell lengths $(\mu \mathrm{m})$ and coefficient of variation $(\mathrm{CV})$.

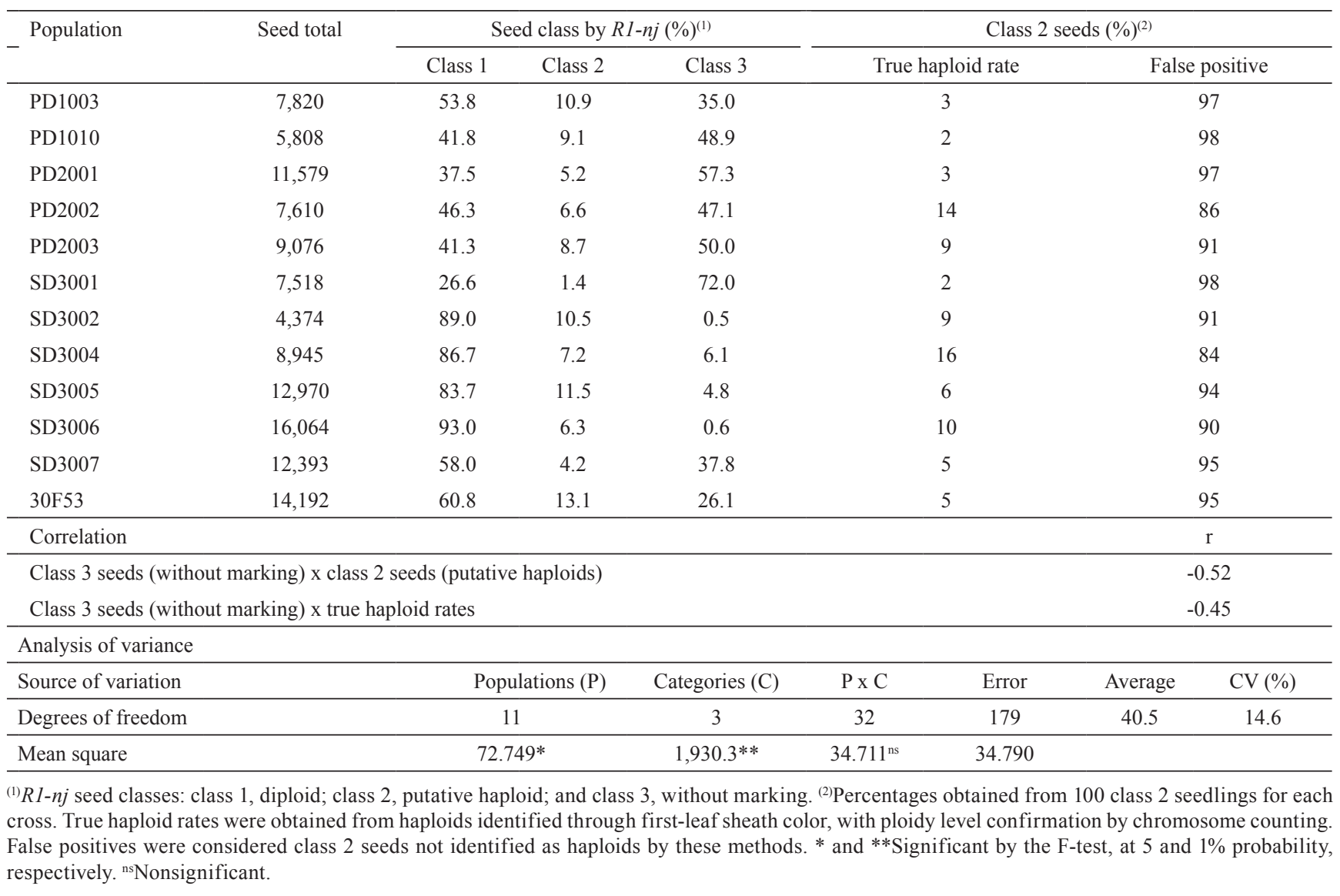


Besides the seeds with $R l-n j$ expression in all the tropical supersweet corn populations evaluated, 26 mosaic seeds were obtained from the haploid induction crosses (Figure $1 \mathrm{E}$ ). Based on observations of mosaic seeds and on cytogenetic examinations of plants induced to haploidy in sweet corn by crossing, Zhang et al. (2008) proposed that the probable mechanism of haploid induction did not completely eliminate inducer chromosomes during haploid-seed formation. According to studies (Zhang et al., 2008), maternal haploidy induction is a phenomenon of chromosome elimination, which can also occur during plant development. These observations suggest more evidence that the tropical supersweet corn genotypes were also producing haploids in crosses involving a maternal inducer.

Even with considerable proportions of putative haploids, the failures resulting from the $R 1-n j$ marker selection require alternative methods to distinguish false positives from true haploids. With regard to haploid identification in supersweet corn populations, the cytogenetic examination of class 2 seedlings, obtained from seeds with purple endosperm and nonpurple embryo, confirmed haploidy in all seedlings with a green first leaf sheath and albino phenotypes (Figure $1 \mathrm{~F}$ and Figure $2 \mathrm{~A} 2$ ). However, all the seedlings obtained from putative haploid seeds (class 2), but that presented a purple first leaf sheath (Figure $1 \mathrm{~F}$ ), were actually identified as diploids based on the same cytogenetic analysis (Figure 2 A1), which indicates the presence of false positives among class 2 seeds. This association between ploidy and a green first leaf sheath strongly indicates that this character can be used in haploid identification at the V2-V3 stage, when inducers are crossed with supersweet corn populations or field corn genotypes with a green first leaf sheath. Other studies have previously reported the use of haploid inducers containing other types of anthocyanin marker genes, such as $B 1$ and $P l l$, to detect haploids by the color of roots or stems (Rotarenco et al., 2010; Choe et al., 2012). However, according to Tracy (2001), over the years, supersweet corn breeding programs have selected genotypes for grains without anthocyanins due to human consumption preference; this result is currently explained by the strong connection between the $s h 2$ allele and the $a l$ anthocyanin inhibitor in many $\operatorname{sh} 2$ supersweet corn varieties.
Since most of the supersweet corn genotypes have no alleles to express anthocyanins (Tracy, 2001), the parental supersweet corn populations used in the present study, as well as their true haploids, also have a green first leaf sheath. Moreover, the field corn genotypes, the inducer, and the 30F53 hybrid (control) have a purple first leaf sheath, which did not allow to identify the true haploids by the color of the first leaf sheath.

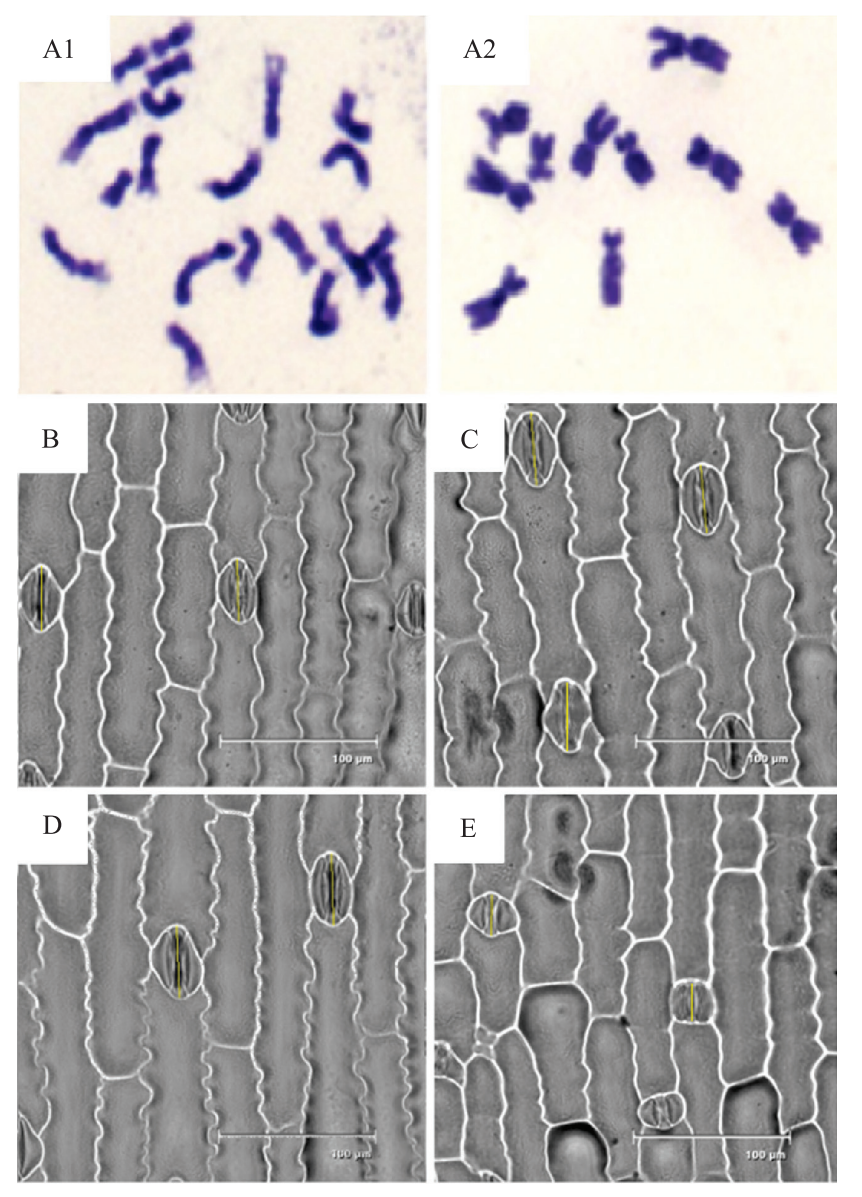

Figure 2. Metaphasic nuclei obtained from supersweet corn (Zea mays L. var. saccharata) root tips and microscopic images of stomata guard cells of V2-V3-stage seedlings, showing: A1, false positive haploids represented by diploid plants with $2 \mathrm{x}=20$ chromosomes; A2, true haploids represented by plants with $\mathrm{x}=10$ chromosomes; $\mathrm{B}, \mathrm{F} 1$ diploid plants, originated from class 1 seeds, based on the R1-nj marker; C, parental non-inducer diploid plants; D, putative haploid plants, originated from class 2 seeds by $R 1-n j$ and confirmed as diploids by chromosome counting; and E, haploid plants, originated from class 2 seeds by $R 1-n j$ and confirmed as haploids by chromosome counting. 
As another method to detect haploids in tropical supersweet corn populations, images of stomata guard-cell measurements showed differences between the diploid (DPF1, PDP, and HPD) and haploid (HPH) categories (Figure $2 \mathrm{~B}-\mathrm{E}$ ).

The factorial analysis of variance revealed a significant effect in populations and categories (Table 1). However, there was no interaction of population $\mathrm{x}$ category, indicating the presence of populations and categories with different mean sizes of guard cells and a proportional reduction in the lengths of these cells in each population, depending on ploidy level.

The comparison of the overall averages of the categories by Tukey's test enabled distinguishing between the diploid categories DPF1, PDP, and HPD and the haploid category $\mathrm{HPH}$, in which haploid plants had a shorter guard cell length than diploid plants
(Figure 3). Because there was no population $\mathrm{x}$ category interaction, this same trend can be considered for the majority of the supersweet corn populations, except for the 30F53 hybrid (control), which had no plants in the HPH category. Based on confidence interval values, a clear difference was found between the haploid and diploid categories for populations PD1003, PD2003, SD3001, SD3002, SD3004 and SD3006, which did not differ among themselves. For PD2001, the parental diploid plants were similar to the haploid plants. However, for all populations in which differences between categories were verified, the average values of the HPH plants were 30 to $48 \%$ smaller than those of the HPD plants. This distinction was not observed only for the supersweet corn populations PD1010 and PD2002.

The upper limit of the average guard cell length of $\mathrm{HPH}$, based on the confidence interval of each

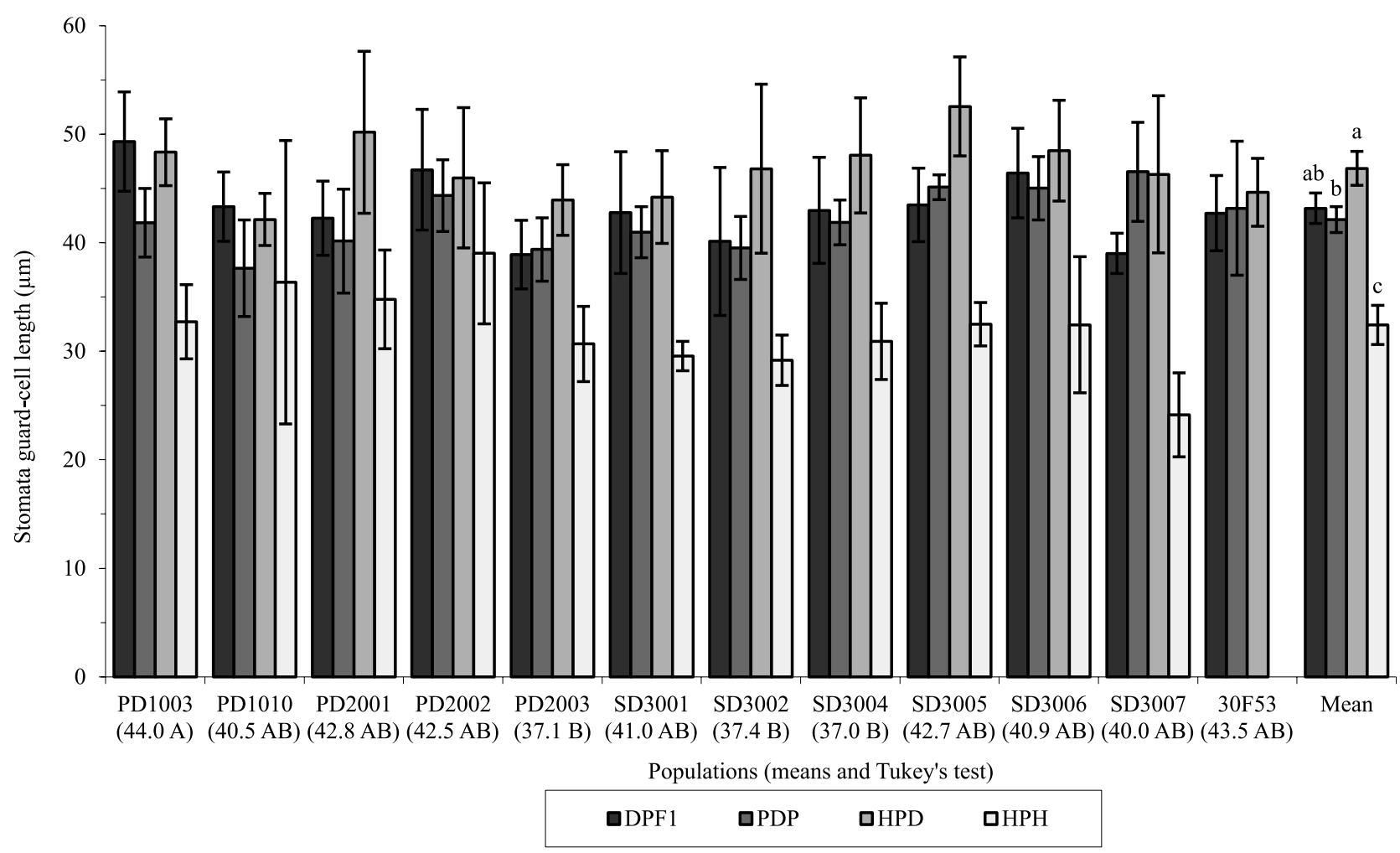

Figure 3. Averages and mean confidence intervals of stomata guard-cell lengths for 12 populations and four plant categories (DPF1, PDP, HPD, and HPH), with respective comparison of the overall average of each category (lowercase letters above the column) by Tukey's test, at 5\% probability. DPF1, F1 diploids originated from seeds of class 1; PDP, parental non-inducer diploid; HPD, putative haploid confirmed as a diploid by chromosome counting; and HPH, putative haploid confirmed as a haploid by chromosome counting. 
population, was used to characterize the 969 class 2 plants that were not assessed by the chromosome counting of all genotypes. The analysis of stomata guard cells showed that 47 plants were defined as haploids. For the 30F53 hybrid (control), using the overall average of the HPH category, five plants were classified as haploids (Table 1). Haploid selection based on stomata guard-cell length of supersweet corn was useful for haploid identification, as also reported by other authors at different stages of field corn development. Using flow cytometry to confirm true haploids and false positives, Choe et al. (2012) discovered that the size of stomata guard cells can differentiate haploid and diploid plants, including false positives, at the early V2 stage. Following the same approach, Molenaar et al. (2019) also noticed that the overlap between stomata measurements of haploids and false positives is really small for plants at the V3-V4 stage. Therefore, the method of measuring stomata guard-cell length could be applied to supersweet corn genotypes at the V2-V3 stage, when it is not possible to identify haploids by the first-leaf sheath color.

Only for PD1010 and PD2002, it was not possible to select haploids using stomata guard-cell length due to a lack of significant differences between the haploid (HPH) and false positive haploid (HPD) categories. This may have occurred because of the low number of haploids detected by the first-leaf sheath color and chromosome counting, used to establish the best confidence interval or the presence of stomata with different morphologies. According to Molenaar et al. (2019), in this method, the number of diploid plants used to plot stomata measurement distribution can influence the misclassification rates of haploids. Therefore, the number of replicates associated with diploid and haploid plants was probably not enough to distinguish the HPH and HPD categories for the PD1010 and PD2002 supersweet corn populations.

The true haploid rates, within class 2 seeds, ranged from 2 to $16 \%$ (Table 1). These results show that the PI4001 inducer is able to induce maternal haploids in tropical supersweet corn populations. However, a great percentage of class 2 seeds were false positives. Using other methods to confirm true haploids among putative haploids, previous works also revealed elevated rates of false negatives, ranging from 22.2 to $89.3 \%$ (Choe et al., 2012) and from 9.3 to $43.0 \%$ (Chaikam et al., 2017). In contrast, using flow cytometry and no coloring by the R1-nj marker, Dang et al. (2012) found 3.8 to $10.2 \%$ false-negative haploids in nonpigmented seeds. In the present study, the correlation between the number of true haploids identified by the firstleaf sheath color and the number of class 3 seeds was -0.45 (Table 1). Similarly, the correlation between the number of putative haploid seeds of classes 2 and 3 was -0.52 . These results show that the number of seeds without marking is inversely proportional to the number of putative haploids and, consequently, the number of true haploids. The low Rl-nj expression in some genotypes also implies a loss of potential haploids not pre-selected by seed coloring. Therefore, alternative methods for haploid identification at early plant developmental stages for both putative haploids and unmarked seeds should be key to improve massive doubled-haploid production.

\section{Conclusions}

1. There is haploid induction in tropical supersweet corn (Zea mays L. var. saccharate) using the PI4001 maternal inducer of field corn (Zea mays L.).

2. Putative haploids of tropical supersweet corn crosses can be pre-selected by the R1-navajo marker.

3 . The green color of the first leaf sheath in seedlings at the V2-V3 stage is useful to determine haploidy for the crosses between tropical supersweet corn populations and the maternal inducer of field corn.

4. Stomata guard-cell morphometry is another useful method for haploid selection of tropical supersweet corn genotypes.

\section{Acknowledgments}

To the graduate program in genetics and molecular biology of Universidade Estadual de Londrina (UEL), for research incentive; and to Coordenação de Aperfeiçoamento de Pessoal de Nível Superior (Capes), for a master's scholarship.

\section{References}

ABD EL-HAMED, K.E.; ELWAN, M.W.M.; SHABAN, W.I. Enhanced sweet corn propagation: studies on transplanting feasibility and seed priming. Vegetable Crops Research Bulletin, v.75, p.31-50, 2011. 
BATTISTELLI, G.M.; VON PINHO, R.G.; JUSTUS, A.; COUTO, E.G.O.; BALESTRE, M. Production and identification of doubled haploids in tropical maize. Genetics and Molecular Research, v.12, p.4230-4242, 2013. DOI: https://doi.org/10.4238/2013. October.7.9.

BEYENE, Y.; MUGO, S.; SEMAGN, K.; ASEA, G.; TREVISAM, W.; TAREKEGNE, A.; TEFERA, T.; GETHI, J.; KIULA, B.; GAKUNGA, J.; KARAYA, H.; CHAVANGI, A. Genetic distance among doubled haploid maize lines and their testcross performance under drought stress and non-stress conditions. Euphytica, v.192, p.379-392, 2013. DOI: https://doi.org/10.1007/ s10681-013-0867-5.

BRENNER, E.A.; BLANCO, M.; GARDNER, C.; LÜBBERSTEDT, T. Genotypic and phenotypic characterization of isogenic doubled haploid exotic introgression lines in maize. Molecular Breeding, v.30, p.1001-1016, 2012. DOI: https://doi.org/10.1007/s11032-011-9684-5.

CASTILlO, A.M.; CISTUÉ, L.; VALLÉS, M.P.; SORIANO, M. Chromosome doubling in monocots. In: TOURAEV, A.; FORSTER, B.P.; JAIN, S.M. (Ed.). Advances in haploid production in higher plants. Dordrecht: Springer, 2009. p.329338. DOI: https://doi.org/10.1007/978-1-4020-8854-4_27.

CHAIKAM, V.; LOPEZ, L.A.; MARTINEZ, L.; BURGUEÑO, J.; BODDUPALLI, P.M. Identification of in vivo induced maternal haploids in maize using seedling traits. Euphytica, v.213, art.177, 2017. DOI: https://doi.org/10.1007/s10681-017-1968-3.

CHAIKAM, V.; NAIR, S.K.; BABU, R.; MARTINEZ, L.; TEJOMURTULA, J.; BODDUPALLI, P.M. Analysis of effectiveness of R1-nj anthocyanin marker for in vivo haploid identification in maize and molecular markers for predicting the inhibition of R1-nj expression. Theoretical and Applied Genetics, v.128, p.159-171, 2015. DOI: https://doi.org/10.1007/ s00122-014-2419-3.

CHAIKAM, V.; PRASANNA, B.M. Maternal haploid selection using anthocyanin markers. In: PRASANNA, B.M.; CHAIKAM, V.; MAHUKU G. (Ed.). Doubled haploid technology in maize breeding: theory and practice. México: CIMMYT, 2012. p.21-24.

CHOE, E.; CARBONERO, C.H.; MULVANEY, K.; RAYBURN, A.L.; MUMM, R.H. Improving in vivo maize doubled haploid production efficiency through early detection of false positives. Plant Breeding, v.131, p.399-401, 2012. DOI: https://doi.org/10.1111/j.1439-0523.2012.01962.x.

COUTO, E.G. de O.; VON PINHO, É.V. de R.; VON PINHO, R.G.; VEIGA, A.D.; BUSTAMANTE, F. de O.; DIAS, K.O. das $\mathrm{G}$. In vivo haploid induction and efficiency of two chromosome duplication protocols in tropical maize. Ciência e Agrotecnologia, v.39, p.435-442, 2015. DOI: https://doi.org/10.1590/S141370542015000500002 .

DANG, N.-C.; MUNSCH, M.; AULINGER, I.; RENLAI, W; STAMP, P. Inducer line generated double haploid seeds for combined waxy and opaque 2 grain quality in subtropical maize (Zea mays. L.). Euphytica, v.183, p.153-160, 2012. DOI: https://doi.org/10.1007/s10681-011-0423-0.
EDER, J.; CHALYK, S. In vivo haploid induction in maize. Theoretical and Applied Genetics, v.104, p.703-708, 2002. DOI: https://doi.org/10.1007/s00122-001-0773-4.

KATO, A. Chromosome doubling of haploid maize seedlings using nitrous oxide gas at the flower primordial stage. Plant Breeding, v.121, p.370-377, 2002. DOI: https://doi.org/10.1046/ j.1439-0523.2002.743321.x.

KRCHOV, L.-M.; BERNARDO, R. Relative efficiency of genomewide selection for testcross performance of doubled haploid line in a maize breeding program. Crop Science, v.55, p.20912099, 2015. DOI: https://doi.org/10.2135/cropsci2015.01.0064.

KWIATKOWSKI, A.; CLEMENTE, E. Características do milho doce (Zea mays L.) para industrialização. Revista Brasileira de Tecnologia Agroindustrial, v.1, p.93-103, 2007. DOI: https://doi.org/10.3895/S1981-36862007000200010.

LÜBBERSTEDT, T.; FREI, U.K. Application of doubled haploids for target gene fixation in backcross programmes of maize. Plant Breeding, v.131, p.449-452, 2012. DOI: https://doi.org/10.1111/ j.1439-0523.2011.01948.x.

MOLENAAR, W.S.; COUTO, E.G. de O.; PIEPHO, H.-P.; MELCHINGER, A.E. Early diagnosis of ploidy status in doubled haploid production of maize by stomata length and flow cytometry measurements. Plant Breeding, v.138, p.266-276, 2019. DOI: https://doi.org/10.1111/pbr.12694.

PRASANNA, B.M.; CHAIKAM, V.; MAHUKU, G. (Ed.). Doubled haploid technology in maize breeding: theory and practice. Mexico: CIMMYT, 2012. 51p.

PRIGGE, V.; BABU, R.; DAS, B.; HERNÁNDEZ RODRIGUES, M.; ATLIN, G.N.; MELCHINGER, A.E. Doubled haploids in tropical maize: II. Quantitative genetic parameters for testcross performance. Euphytica, v.185, p.453-463, 2012a. DOI: https://doi.org/10.1007/s10681-012-0626-Z.

PRIGGE, V.; SÁNCHEZ, C.; DHILLON, B.S.; SCHIPPRACK, W.; ARAUS, J.L.; BÄNZIGER, M.; MELCHINGER, A.E. Doubled haploids in tropical maize: I. Effects of inducers and source germplasm on in vivo haploid induction rates. Crop Science, v.51, p.1498-1506, 2011. DOI: https://doi.org/10.2135/ cropsci2010.10.0568.

PRIGGE, V.; XU, V.; LI, L.; BABU, R.; CHEN, S.; ATLIN, G.N.; MELCHINGER, A.E. New insights into the genetics of in vivo induction of maternal haploids, the backbone of doubled haploid technology in maize. Genetics, v.190, p.781-793, 2012b. DOI: https://doi.org/10.1534/genetics.111.133066.

QIU, F.; LI, Y.L.; LIU, Y.; WANG, L.; ZHENG, Y. Morphological, cellular and molecular evidences of chromosome random elimination in vivo upon haploid induction in maize. Current Plant Biology, v.1, p.83-90, 2014. DOI: https://doi.org/10.1016/j. cpb.2014.04.001.

ROTARENCO, V.; DICU, G.; STATE, D.; FUIA, S. New inducers of maternal haploids in maize. Maize Genetics Cooperation Newsletter, v.84, p.1-7, 2010.

TRACY, W.F. Sweet corn. In: HALLAUER, A.R. (Ed.). Specialty corns. $2^{\text {nd }}$ ed. Boca Raton: CRC Press, 2001. p.162-205. 
WU, P.; LI, H.; REN, J.; CHEN, S. Mapping of maternal QTLs for in vivo haploid induction rate in maize (Zea mays L.). Euphytica, v.196, p.413-421, 2014. DOI: https://doi.org/10.1007/s10681-0131043-7.
ZHANG, Z.; QIU, F.; LIU, Y.; MA, K.; LI, Z.; XU, S. Chromosome elimination and in vivo haploid production induced by Stock 6-derived inducer line in maize (Zea mays L.). Plant Cell Reports, v.27, p.1851-1860, 2008. DOI: https://doi.org/10.1007/ s00299-008-0601-2. 